This item was submitted to Loughborough's Research Repository by the author.

Items in Figshare are protected by copyright, with all rights reserved, unless otherwise indicated.

\title{
From competitive regions to competitive city-regions: a new orthodoxy, but
} some old mistakes

PLEASE CITE THE PUBLISHED VERSION

\section{PUBLISHER}

(c) Oxford University Press

\section{VERSION}

AM (Accepted Manuscript)

\section{LICENCE}

CC BY-NC-ND 4.0

\section{REPOSITORY RECORD}

Harrison, John. 2019. "From Competitive Regions to Competitive City-regions: A New Orthodoxy, but Some Old Mistakes". figshare. https://hdl.handle.net/2134/4399. 
This item was submitted to Loughborough's Institutional Repository (https://dspace.lboro.ac.uk/) by the author and is made available under the following Creative Commons Licence conditions.

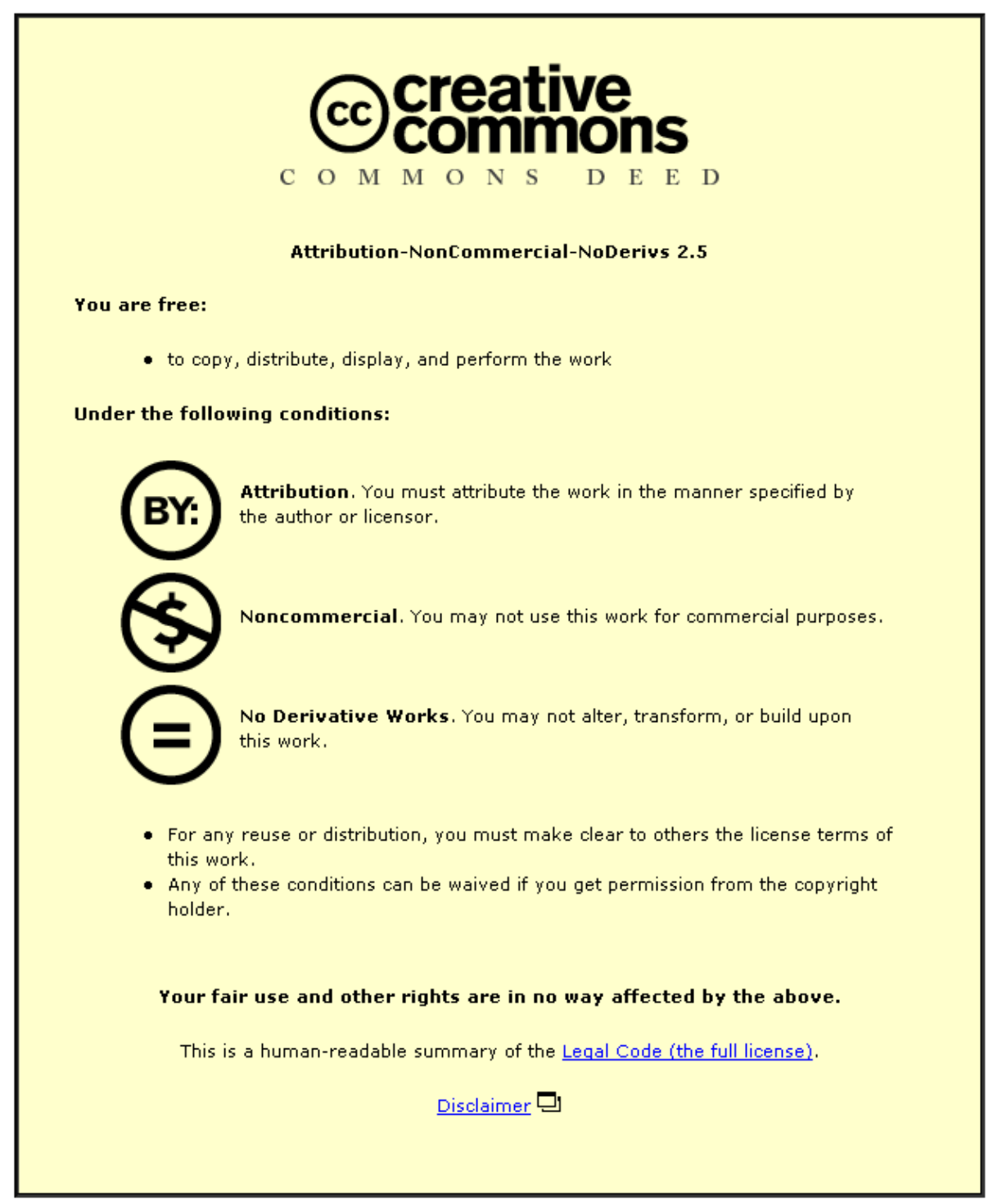

For the full text of this licence, please go to: http://creativecommons.org/licenses/by-nc-nd/2.5/ 


\section{From Competitive Regions to Competitive City- Regions: A New Orthodoxy, But Some Old Mistakes}

'Will we witness the emergence of the 'city-region' as the future arena for partnership, capacity building and intervention on planning matters?"

Tewdwr-Jones and McNeill (2000: 120)

\section{Introduction: the rise of the city-region}

For many, globalisation is the relentless force that has come to characterise and shape the capitalist state in which our daily lives operate. At one level, the complex web of flows and processes spawned by globalising forces appear to have homogenised practice across an increasingly borderless world. Much less evident in the prevailing discourse, but surely of equal importance and practical significance, has been a new regionalism that is countering this notion of the world as a borderless space of flows. Not to be viewed as the antithesis of globalisation, the new regionalism represents the conceptual belief that while some flows and processes are becoming increasingly distanced from the confines of place, a range of counteracting flows and processes are increasingly rooted in a series of place-sensitive nodes of dense economic and social activity.

Much documented in the new regionalist literature, the point of departure from this well-rehearsed debate is the observation that the emergence of the new regionalism appears to coincide with the resurgence of another territorial form, that of the city. In what remains the most 
comprehensive account documenting the rise to prominence of city-regions in the global economy, Allen Scott's book Global City-Regions i argues how, when presented together, "city regions are coming to function as the basic motors of the global economy, a proposition that points as a corollary to the further important notion that globalisation and city-region development are but two facets of a single integrated reality" (Scott, 2001: 4).

Current interest in the scale of the city-region marks a new stage in the rapidly intensifying debates about the rise of regional states of politicaleconomic governance, organised and aligned around a series of globally interlinked city-based economies ${ }^{\mathrm{ii}}$. More than just new politically-orchestrated territorial forms, these new city-oriented regional states have grown to prominence in strategically developing and shaping the course of the new capitalist world economy. The ascendancy of city-regions as territorial platforms for leading edge developments in the contemporary capitalist economy has led some to identify their existence as evidence of 'global citycentric capitalism' (Brenner, 1998), while the renaissance of city-regionalism could also be seen to constitute a new and distinctive postnational phase in the territorial development of capitalism. Not until recently, however, have debates sought to grasp the initiative to make explicit the connections between resurgent cities and the new regionalism (Ward and Jonas, 2004).

Under the titles of 'global city-regions' (Scott, 2001) and the new 'city regionalism' (Ward and Jonas, 2004), there has been a growing support for a resurgence of city-regions within economic geography. Moving away from new regionalist accounts claiming that contemporary capitalism and its territorial configuration were best regulated and governed in and through the 
decentralisation of socioeconomic decision-making and associated policy implementation to regional institutional frameworks and supports, it is now city-regions that are seen to "function as territorial platforms for much of the post-Fordist economy that constitutes the dominant leading edge of contemporary capitalist development, and as an important staging post for the operation of multinational corporations" (Scott, 2001: 4).

In contrast to the overwhelming plethora of accounts that now support the rise of the city-region concept (for a flavour see Hall and Pain, 2006; Lloyd and Peel; 2006; Parr, 2005; Scott, 2001; Ward and Jonas, 2004), this paper reflects on the experiences of the new regionalism to offer some sobering reflections on the ascent to orthodoxy of the new city-regionalism within economic geography. Many tensions emerged from within the new regionalist literature, variously documented across the breadth of political and economic geography, but for the purposes of this paper I will concentrate on the critiques provided by Lovering (1999), MacLeod (2001b), and Harrison (2006b). Despite offering contrasting views on the move beyond the new regionalism, these papers are important given that they retain a commonality and a consensus with regards to a series of critical weaknesses identified in the new regionalism. More importantly, this paper argues that these weaknesses have important connotations for the new city-regionalism, and raise important questions for the future of economic geography more broadly.

While sympathetic to the general tenor of the new city-regionalism, this paper argues for a more synthetic approach to understanding the significance of the city-region as an effective arena for positioning economic governance. It argues that the current level of focus and attention that is afforded by both 
academic and policy communities to the city-region in political-economic debates is at best premature and, at worst, overblown. As economic geographers we are frantically trying to keep afloat in the midst of the diversity of papers flooding into the literature to capture the evolving landscape of ideas and practices within the 'pot-pourri' of different dimensions that reflect the "real politik of political, institutional, governance, public policy, economic, social, environmental, physical, and cultural dimensions" that are our cityregions (Lloyd and Peel, 2006: 285). As such, this paper advocates a period of critical theoretical and empirical interrogation, rather than what has become the customary race to find the next new orthodoxy (in this case the new city regionalism), adopt it with great haste, and bombard economic journals and books with supportive and mutually reinforcing commentaries.

Like the new regionalism that preceded it, the orthodoxy surrounding the new city-regionalism in economic development is particularly important given its support by academics, political leaders, and practitioners (compare Hall and Pain, 2006; HM Treasury et al., 2006; Jones et al., 2006a; NLGN, 2005; ODPM, 2004; Scott, 2001; Ward and Jonas, 2004). Similarly, the new city-regionalism and its impacts are particularly evident in recent political praxis in England. Originally part of the new regionalist inspired agenda of devolution and constitutional change in the United Kingdom, England (and her eight regions) reflect the sole territorial space(s) within the kingdom that operate(s) without an adequate set of subnational institutional arrangements ${ }^{\mathrm{iii}}$. In contrast to the institutions devolved to Scotland, Wales, Northern Ireland and London, and despite the creation of Regional Development Agencies (RDAs) and Regional Assemblies (RAs) alongside the existing Government 
Offices for the Regions (GORs), the English regions remained without a fully democratic tier of regional governance.

Spurred on by the wave of optimism surrounding the creation of a Parliament in Scotland, a National Assembly in Wales, and a new city-wide authority with elected mayor in London, England was granted the opportunity to ascend to a fully-fledged new regionalist tier of regional governance through proposals to create directly-elected regional assembly's (ERA) (DTLR/Cabinet Office, 2002). However, an apathetic nature towards regionalism in England, and the landslide rejection of the governments proposals for an ERA in the North East Regional Referendum (November 2004), dealt a powerful body blow to England's New Regional Policy (NRP) (Harrison, 2006a). So as the door apparently closed on Labour's new regionalist project in England ${ }^{\text {iv }}$, the door to enable the rise of the city-region concept in the polity of England's subnational governance became wedged firmly open. Through a reflective commentary of the experiences of the new regionalism, this paper argues that blending theoretical conceptualisation with grounded empirical evidence can offer new understandings on the new cityregionalism in economic geography.

Following discussion of the new regionalist thinking and its various weaknesses (section 2), this paper provides a case-study of the current restructuring of economic development in England through the regulatory frameworks being established as part of the emerging city-regional agenda (section 3). Since the progressive institutionalisation of regions began to splutter and stall in the wake of the landslide rejection of the proposed centrepiece of the governments NRP, the city-region became an increasingly 
important arena for the concentration of academic and political interest in the quest to embrace the hegemonic discourse of regional competitiveness (Bristow, 2005). What remains unexplored to date, however, are the politicaleconomic implications of such a sudden territorial and scalar shift in the positioning of the regional competitiveness discourse from an agenda explicitly couched in the new regionalist idea of competitive regions to a new city-regionalist inspired notion of competitive city-regions.

With the identified weaknesses from the new regionalism fresh in our minds, this paper critically evaluates the degree to which the new city-region orthodoxy that is blossoming in the economic geography literature, and the associated processes of city-regionalism that are being observed in the policy and strategy development of capitalist economies, have taken heed of the lessons that are to be learnt from the experiences of the new regionalism. Finally, this paper speculates on the wider implications that this has for the pursuit of truly critical economic geography in the future.

\section{From new regionalism to new city-regionalism}

If the new regionalist zenith was achieved with the publication of Storper's The Regional World (1997), Scott's Regions and the World Economy (1998), Keating's New Regionalism in Western Europe (1998), and Cooke and Morgan's The Associational Economy (1998), then it can be argued that the new regionalism reached its nadir a year later with the publication of Lovering's (1999) evocative critique, Theory Led by Policy: The Inadequacies of the New Regionalism. Although the merits of Lovering's approach to critique have long been debated - this line of criticism was not 
new, for Lovering (1995) previously attacked the new localism from a similar position, and indeed, he has recently taken forward this critical stance in a disparaging attack on post cultural-turn economic geography (Lovering, 2006) - there were clearly pertinent issues raised in his paper that had been (un)knowingly swept under the proverbial carpet by authors rushing to endorse this new regionalist orthodoxy.

To begin, Lovering argues that the new regionalism is characterised by four key features: it is a highly selective amalgam of 'all things good' in the regional economies of the world today; new regionalist case-studies tell an 'attractive and persuasive story' based on carefully selected exemplar regions; it has emerged as a fashionable banner offering both a convincing theoretical explanation and for its followers the best approach to policy formation; and, related to the above points, the conclusion is made that "the policy tail is wagging the analytical dog and wagging it so hard that indeed much of the theory is shaken out" (Lovering, 1999: 390). For Lovering, the new regionalism is simply "a set of stories about how parts of a regional economy might work, placed next to a set of policy ideals which might just be useful in some cases" (Lovering, 1999: 384 original emphasis).

Though much cited by academics - and variously labelled as 'imaginative and rousing', 'highly provocative', 'deeply contentious' (MacLeod, 2001b), a 'piercing academic critique' (Jones, 2001), and a 'hard-edge and negative critique' (Harrison, 2006b) - it remains noticeable how Lovering's critique of the new regionalism attracted little response from the very authors that were responsible for its ascent to orthodoxy within economic geography, and to whom Lovering's angst was directed. Despite this timely intervention, it 
has been argued that Lovering was unable to provide the necessary theoretical and conceptual tools to move beyond what he identified as the chaos and irrational logic behind the new regionalism (MacLeod, 2001b; Harrison, 2001b). As such, this author concurs with the view that Lovering's (1999) critique "is essential for getting the new regionalism in perspective" (Jones, 2001: 1190), but that this 'perspective' needed enlightening through further work that sought to posit the theoretical and conceptual tools required to move beyond the new regionalism and its inadequacies.

Responding directly to Lovering, MacLeod's (2001b: 805) more considered critique sought to offer some "sobering reflections on what might be recovered" to partially rescue the new regionalism from its inherent lines of weakness. While sympathetic to the general tenor of Lovering's critique, MacLeod's more pragmatic synopsis for moving beyond the new regionalism made the case for a theoretical reconstruction of the new regionalism through a 'geopolitically sensitive regional research agenda' that pays particular attention to the restructuring of the state (MacLeod, 2001b). Firmly rooted in the tradition of the Regulation Approach, MacLeod's argument that the important multifarious processes that are intertwined with economic globalisation and the purported resurgence of cities and regions are "throwing down some fundamental challenges" for our conceptual understandings of the national state, was critical in providing one particular avenue of research that moves beyond the new regionalism in economic geography (MacLeod, 2001b: 806).

Developed in light of this new regionalist debate, an alternative approach to MacLeod's theoretical reconstruction of the new regionalism was 
recently forwarded. Arguing that MacLeod's reconstruction was too narrowly focused on a theoretical reconstruction of the new regionalism - one that was not sensitive to the actual practicalities of 'doing' regional regulation - this alternative reconstruction of the new regionalism outlined a new methodological framework to blend the theoretical with the empirical; through a multi-dimensional and multiscalar, empirically grounded, single-region case study approach that opens up new possibilities for gaining deeper readings of the complex form, function, and character of regions, and the dynamic processes which shape them (Harrison, 2006b). It is this notion of empirically thick, yet theoretically grounded research that I want to deploy here to take forward debates surrounding the ascent to orthodoxy of the new cityregionalism in economic geography.

Shaped by different motivational agendas in the move beyond the new regionalism, what is often overlooked is how these papers retain a certain degree of commonality and consensus with regards to a series of critical weaknesses identified within the new regionalism. Firstly, by bundling together too many diverse theories for it to be considered a coherent body of work, the chaotic nature of the new regionalism has served to distance political-economic geographers from explicitly engaging with their 'supposedly foundational concept' (Lovering, 1999). To be sure, the region remains an ‘object of mystery' within economic geography (Harrison, 2006b). Secondly, the new regionalism is "a poor framework through which to grasp the real connections between the regionalisation of business and governance and the changing role of the state" (Lovering, 1999: 391), which "barring a few exceptions... has either disregarded the changing role of the state or implied 
that, amid the current round of globalisation-regionalisation, it is inevitably in terminal decline" (MacLeod, 2001b: 806).

Related to this absence of the state in much of the new regionalist literature, a third concern has centred on how the new regionalism has become enmeshed in multifaceted scalar politics and associated tangled policy hierarchies (Harrison, 2006b). Building on MacLeod's (2001a; 2001b) analysis of 'thin political economy' in the new regionalism, and the requirement to explicitly focus on the role played by the state in the remaking of both regional economies and their structures of governance, there is a broader obligation upon economic geographers to examine the increased complexity in the way that the state produces, reproduces, and articulates the scalar and spatial sites of economic governance (Brenner, 2004).

Reinforcing these first three weaknesses, a fourth concern has developed from Lovering's (1999) catchy metaphor, 'the policy tail is wagging the analytical dog', which focuses on the dangers of soft institutionalism and programmes of policy transfer. Sceptical of imported policy solutions, the new regionalism was, somewhat paradoxically, drawn to favour those policy measures that are informed by the perceived commonalities found in the development of prosperous regions. While some regulatory institutions may in a structural sense be replicated elsewhere, their operation and effects most certainly cannot be repeated. Of all the weaknesses, this paradox endangered the new regionalism the most because while institutions do have effects, there can be no absolute guarantees as to their effects; regional policies designed to imitate growth regions cannot account for the effects of state regulation; the effects of institutions are guided by a set of unique local conditions; and, the 
time-lag between the creation of institutions in successful and less favoured regions cannot be accounted for (Harrison, 2006b). Indeed, as the events surrounding the collapse of the NRP in England have highlighted, these inherent lines of weakness within the new regionalism have had major repercussions for the state restructuring of subnational economic governance (Harrison, 2006a). The question that remains unanswered in the current race to adopt the new city-regionalism, however, is whether these same weaknesses that undermined the new regionalist programme of economic governance, will similarly undermine the new city-regional agenda that is sweeping through economic geography? It is to this question that this paper now turns, through an empirically supported reading of the new cityregionalism.

\section{The Rise of the City-Region Concept in England}

The recent (re-)emergence of city-regions in the spatial governance of England has been the result of a key focus within political-economic debates over the differences between economic and administrative boundaries, and how subnational organisations and institutions - ranging from the community to the region - could contribute further to localised economic development. Over the past twenty-five years these debates have seen a three-phase shift in the focus of state projects at the subnational level. Firstly, economic development policies from the 1980s onwards saw the arrival of various public-private partnership policy measures that were established as alternatives to direct local government intervention at the scale of the city Urban Development Corporations (1980), City Challenge (1991) and the 
Single Regeneration Budget (1994). Derived from the fallout from UDCs and City Challenge, and the transfer of SRB to the newly established GORs, the second phase concentrated on the recognition that the public-private partnerships, which had been characteristic of the urban-local scale in phase one, were now being replicated at the regional level in the mid-1990s. The new requirement for strategic planning at the regional level at this time renewed debate surrounding the periodic problem facing England; an overheating economy in the Greater South East and underperforming economies in the North of England (Peck and Tickell, 1995).

With continued economic growth over the last decade, Blair's Labour Government recognised that the rapid expansion of London and the South East was outgrowing the regional housing and transport infrastructure. Thus, contained within Labour's programme of devolution and constitutional that afforded the English regions with RDAs and indirectly-elected RAs, the settlement for London had its origins in the notion of competitive cityregionalism. Led by an elected Mayor (Ken Livingstone ${ }^{v}$ ), the new Greater London Authority represented the formal collaboration of public-private partnership working at the level of the city-region in order to provide a territorially institutionalised platform from which to secure London and the South East's position in the global economy. Indeed, it was at this time that academics and policy practitioners began to question whether we were witnessing the emergence of the city-region as the future arena for intervention in the political and economic regulation of the state (TewdwrJones and McNeill, 2000). 
With disparities between the Greater South East and the peripheral regions of England continuing to spiral out of control under Blair's Labour government, there appeared to be a number of possible solutions to accommodate the high levels of growth in and around London: restrict growth and slow the over heating of the South East; create new investment in the lagging regions (especially in northern England); or, spatially intervene and manage the physical location of industry through programmes of relocation out of the South East. Outlined in Sustainable Communities: Building for the Future (SCP) (ODPM, 2003), the governments proposals for the strategic regional planning of England made for interesting reading.

Launched in February 2003 by the Deputy Prime Minister (DPM) John Prescott, the Sustainable Communities Plan (SCP) outlined the governments $£ 22$ bn commitment to accommodate the economic success of the Greater South East through a demand-side programme spatially concentrated on the development of four growth areas located in what is known as the South East mega-city region (Hall and Pain, 2006) ${ }^{\mathrm{vi}}$. Published eighteen months before the collapse of the NRP in England, the government's political allies in the north were distinctly under-whelmed by the state's decision to focus policies towards accommodating growth in the South East, rather than addressing spatial inequalities across England. Some commentators went so far as to suggest that the government's policy was like 'a slap in the face for many in the North' (Robson, 2004).

In the midst of the political fallout from the SCP, government ministers moved swiftly to open up a new 'Northern Way' programme - Making it Happen: The Northern Way (ODPM, 2004) - to bring Northern England 
forward in the economic development and spatial planning of England. In its infancy the Northern Way was based on a spatial growth corridor that ran west-east from Liverpool to Hull, and a secondary north-south corridor connecting Newcastle and Leeds. Despite speculation from sceptics that the exercise was largely 'cobbled together' by Prescott's advisors and civil servants in the Office of the Deputy Prime Minister, at the programme's launch in Manchester, the DPM remained resolute in his belief that the Northern Way would "provide the framework for growth that can match the growth corridors of the Thames Gateway" (Prescott quoted in ODPM, 2004: 1).

Irrespective of the lack of substance that lay behind the glossy front cover - the sole funding support for the programme came from a $£ 100 m$ growth fund - and the ready acknowledgement that the programme conveniently filled the political void left by the SCP, the Northern Way received enthusiastic overtures from political leaders and commentators within the North of England:

"This was an initiative which appeared out of nowhere and which, at the time, seemed to amount to little more than a sound bite designed for media consumption. But it may turn out that the Northern Way could end up being one of the most significant initiatives in regional economic policy for a number of years."

$\operatorname{Adams}^{\text {vii }}(2004: 1)$ 
So how did a project that was 'willing the ends but not providing the means' (Hetherington, 2004) potentially become one of the most significant initiatives in the economic governance of the English regions? Somewhere contained within these threadbare proposals for the creation of a Northern Way model for spatial economic development in England, there had to be a political thread that resonated with the political leaders and key economic stakeholders of Northern England.

Despite a lack of substance in the proposals, leaders in the north of England realised that without a major injection of enthusiasm and leadership to turn these aspirations into a fully implementable programme, the Northern Way project would fall by the political wayside. Dubbed "a once in a lifetime opportunity for the North of England to shape its own destiny by bringing about change - the Northern Way" (Northern Way Steering Group, 2005: 3) the three northern RDAs - One North East, Northwest Development Agency, and Yorkshire Forward - were challenged to outline what the North should do differently to unlock the potential for faster economic growth and begin to bridge the $£ 29$ bn productivity gap with the South of England. As the RDA taskforce began consulting the economic leaders of the northern regions, it became apparent that the challenge facing the taskforce mirrored that which had been occupying the minds of leaders in the major regional cities of England.

Established in 1995, the city councils of eight regional cities in England - Birmingham, Bristol, Leeds, Liverpool, Manchester, Newcastle, Nottingham and Sheffield - began working together to ensure that their profile compares favourably with the leading regional cities internationally, through the 
development of a vision detailing the distinctive role that large cities play in their regional and national economy. The initial informal association was formalised through the establishment of England's 'Core Cities Group', whose mission was to:

"Demonstrate the role of England's cities in increasing regional prosperity and narrowing the gap between English regions. Building on the fruitful dialogue now underway between the Core Cities, Government Departments and Regional Development Agencies, and following the example set by successful European cities, there is a need to develop positive policy and practical measures at local, regional and national levels to specifically address the performance gap between English regions, and to help cities fulfil their economic potential."

Core Cities Mission Statement

While both were championed by the same government department (ODPM), and the territorial politics of both can be seen as a spatial-political response to uneven development (i.e. the perception of disparity between the South East and the remainder of England), what became increasingly noticeable was that the Core Cities Group and the RDAs were working at different scales - the city and region respectively - towards a solution to the same economic challenge. With political debate concentrated on the political progression of the NRP in 2003-04, the city-regional agenda was slowly 
bubbling away under the surface through the work of the RDA-led taskforce and the Core Cities Group (ODPM, 2003; Core Cities Group, 2004).

Ironically, it was on the campaign trail for the regional referendum on ERAs that the DPM brought together the twin-tracks of the broader regional dimension - the constitutional, through the limited political devolution to the regions, and the economy, through the work of the RDAs and their links with HM Treasury, ODPM, and the Department of Trade and Industry (Tomaney and Hetherington, 2004) - to pave the way for a new English city-regionalism.

Combining the efforts of the northern RDAs and the Core Cities Group, the re-launch of the revitalised 'Northern Way' programme - Moving Forward: The Northern Way (NWSG, 2004) - eradicated the memory of growth corridors and marked the first indication that competitive city-regionalism was now firmly on the government agenda. A matter of a few months later, with the landslide rejection of the governments proposals for ERAs effectively closing the door on the new regionalist policy in England for the foreseeable future, the door for the new city-regionalism to replace the new regionalism as the orthodoxy in economic geography, and the city-region to replace the region as the territorial focal point for subnational economic governance was firmly open. Illustrative of this, a paradigmatic shift could also be observed in the policy discourse emanating from the state at this time:

"We recognise the need to evolve our approach further to ensure that regional and local institutions have the capability, capacity and confidence to overcome regional economic disparities. Increasing institutional flexibility around targets, funding and central guidance, tied 
to stronger accountabilities and performance incentives, will help national, regional and local institutions work better together. The Regional Development Agencies, in particular, have an excellent understanding of what is needed to drive economic growth in the regions."

Devolving Decision Making: 2 - Meeting the Regional Economic Challenge: Increasing Regional and Local Flexibility

HM Treasury et al. (2004: foreword)

"Cities represent the spatial manifestations of economic activity - large, urban agglomerations in which businesses choose to locate in order to benefit from proximity to other businesses, positive spillovers and external economies of scale. This document sets out how successful cities can contribute to competitive regions, stimulating growth and employment, promoting excellence in surrounding areas and joining up separate business hubs to expand existing markets and create new ones...This document extends the analysis and understanding of the economic role of cities and regions in lifting regional and national growth, and tackling disparities between places. It examines the drivers of, and constraints on, the economic performance of cities. It identifies the policy challenge in enabling English cities to build on recent economic growth, improve economic performance and catch up to international counterparts." 
Devolving Decision Making: 3 - Meeting the Regional Economic Challenge: The Importance of Cities to Regional Growth

HM Treasury et al. (2006: 1)

Discussion around the rise to prominence of the city-region for unlocking economic growth has gathered further momentum within the corridors of Westminster and Whitehall through the proliferation of government think-tanks and leading political figures adding their backing to the idea of competitive city-regionalism (Jones et al., 2006a; Kelly, 2006; Marshall and Finch, 2006; NLGN, 2005; Marvin et al., 2006; SURF, 2004). Even at this early stage, the city-region agenda in England has developed so that relational processes and trans-regional networked forms of governance are being opened up to fresh approaches across both territorial space and scale. Responding in kind to the development of the Northern Way, regions lying outside the remit of this trans-regional and relationally networked programme have moved swiftly to develop and formalise their own strategic plans. With the South East benefiting from the SCP and Northern England from the Northern Way, the East and West Midland regions believed that they "had been left to fend for themselves in a no-man's land of regional policy" (TCPA, 2005). Not wishing to 'miss out', the Midland regions produced their very own growth strategy - Smart Growth: The Midlands Way (AWM/EMDA, 2005). Subsequent to this, the South West region has moved to develop The Way Ahead: Delivering Sustainable Communities for the South West, and in the East of England a new Regional Cities East organisation has been established $^{\text {viii }}$. Together, these policy developments could be seen as 
"amounting to a trans-regional and relationally networked embryonic national spatial plan" for England (Jones et al., 2006b: 14). What remains unanswered, however, is whether the same weaknesses that undermined the new regionalism have been collapsed into the new city-regional agenda. Supported by further empirical evidence from the political praxis currently operating in England, it is to this question that the final part of this paper explores.

\section{The New City Regionalism: New Orthodoxy, Same Old Mistakes?}

Such a dramatic shift in the policy rhetoric of the British state from 'regions' in 2004 to a new discourse of 'cities and regions' by 2006 raises a number of questions, through which it is argued can provide the opening for a much needed critical appraisal of the position of orthodoxy afforded to the new city-regionalism within economic geography, its cognate disciplines, and political praxis. This section questions whether the new city-regionalism has rescaled rather than resolved the problems by collapsing the weaknesses identified in the new regionalism into the new city-regionalism.

\subsection{City Regions: Objects of Mystery}

In recent history the roots of the city-region concept can be traced to a series of sporadic yet seminal works that appeared throughout the twentieth century (Fawcett, 1919; Dickinson, 1964; 1967; Hall et al., 1973). Each in their time brought the city-region to the forefront of academic and political debate, but it is the work of Dickinson that provides the conceptual framework from 
which the most recent analysis of the city-region concept takes as its starting point.

Following an initial flurry of excitement surrounding city-regions in the late 1960s, the city-region concept reached the apex of it its academic and policy attention in the mid-1970s (Hall et al., 1973), from which it then began a slow and steady decline into its relative obscurity during the 1980 s. What appears here to be nothing more than a simple historical tale of the rise and fall of the city-region concept (1960-1980) actually contains important links to the current debate surrounding the transition from regions to city-regions. Scholars are ready to acknowledge Dickinson (1967) by way of a cursory reference in their opening remarks to new city-regional commentaries (Lloyd and Peel, 2006; Parr, 2005), but few, if any, stay around long enough to make the important links between Dickinson's seminal work on city-regions and its application to contemporary discussions. Here it is argued that too much haste has prevented critical reflective thinking and obscured further understanding of city-region programmes operating in political praxis.

Remembering the important transition from competitive regions to competitive city-regions in the evolving economic geography of the present day, it is particularly revealing to look beyond the narrow focus that many scholars adopt when highlighting Dickinson's seminal works on city-regions. Ironically, in the period of decline for the city-region concept in the 1970s, it was Dickinson himself who coined the phrase 'the regional concept', to promote the centrality of 'the region' to the theory and practice of human geography and its cognate disciplines (Dickinson, 1976). Often overlooked, back in the 1970s Dickinson's leap from the retreating conceptual orthodoxy 
of the city-region, to the new and rising regional orthodoxy that produced the new regional geography of the 1980 s, and subsequently the new regionalism of the 1990s, offers a striking resemblance to the reversal in orthodoxy between regions and city-regions observed presently.

Despite this revitalisation of the 'regional concept' over recent decades, what remained constant throughout, is that the region remained 'an object of mystery', with an unqualified definition of what a region actually is (Harrison, 2006b). And herein lies the second valuable insight provided by Dickinson. If for one moment we reflect upon the essence of Dickinson's conceptualisation of city-regions, striking similarities emerge between this and the much citied work of Allen et al. (1998) on the social construction of regions:

"This concept of the city-region, like all concepts, is a mental construct. It is not, as some planners and scholars seem to think, an area that is presented on a platter to suit their general needs. The extent of the area they need will depend on specific purpose for which it is required. The concept of the city-region can only be made specific and definable, as a geographic entity, by reference to the precise and areal extent of particular associations with the city."

Dickinson (1964: 227)

"Regional studies are always done for a purpose, with a specific view. Whether territorial, political, cultural or whatever, there is always a specific focus. One cannot study everything, and there are always multiple ways of seeing a place: there is no complete 'portrait of a 
region'. Moreover, 'regions' only exist in relation to particular criteria. They are not 'out there' waiting to be discovered, they are our (and others') constructions."

Allen et al. (1998: 2)

Though written over two decades apart, clear parallels emerge between the conceptualisation of the city-region in the 1970s and the region in the 1990s: specifically, there are multiple ways of seeing each place; they exist in relation to particular associations/criteria; and they are always socially constructed. So what does this mean for the re-emergence of city-regions presently?

In the midst of the new regionalist orthodoxy, it was only a decade ago that Storper (1997) famously suggested that we were living in a 'regional world' where regions were the fundamental building blocks for a globally interconnected capitalist state. Today, the new regionalism is no longer the fashionable banner that it once was. While new regionalist approaches and interventions continue to inform us of how political-administrative regions are strategic scalar anchor points within the increasingly complex multi-level, multi-scaled, and multi-tiered system of economic capitalism, this very notion of regional space has been challenged by those who advocate a 'relational' approach to understanding and conceptualising spatiality:

"If we are to see...regions as spatial formations, they must be summoned up as temporary placements of ever moving material and immanent geographies, as 'hauntings' of things that have moved on 
but left their mark as situated moments in distanciated networks, as contoured producers of the networks that cross a given place. The sum is cities and regions without prescribed or proscribed boundaries."

Amin (2004: 34 original emphasis)

"Space is no longer seen as a nested hierarchy moving from 'global' to 'local'. This absurd scale-dependent notion is replaced by the notion that what counts is connectivity."

Thrift (2004: 59 emphasis added)

What can perhaps be argued as the inherently antigeographical (and antipolitical) thrust of much of the current 'relational turn' presents a particular challenge for conceptualising cities, regions, and city-regions, given that "emerging spatial configurations are not necessarily or purposively territorial or scalar but are constituted through the spatiality of flow, porosity, and connectivity" (Jones et al., 2006b: 3). Striking in its appearance, it is clear that the territorial emphasis for subnational economic governance in political praxis (HM Treasury et al., 2004; 2006), has run parallel to these theoretical debates within economic geography. With England's NRP very much at the forefront of the political agenda in 2004, the policy discourse deployed by the state focused explicitly on the role played by political-administrative regions in securing competitive advantage in the global economy, whereas following the collapse of the NRP in late 2004, a new 'relational' policy discourse that focuses on cities and regions emerged in the equivalent government document from 2006 (see Section 3). 
My argument here is that while new regionalist scholars struggled to grapple with their foundational concept, such that the region has remained an 'object of mystery', the same challenge is now a centrally embedded component of debates surrounding the emergence of a new city-regionalism; notably, what it a city-region? Similar to current debates within planning on spatial strategy making and 'spatial planning and governance', city-regions as a new set of ideas and agendas, politically, almost defy theoretical constructs since they are fluid, diverse and characterised by difference. Links between the social construction of city and regional space, and the concept of relational space, are thus critical for understanding the dynamics and institutionalisation of city-regions as we constantly move beyond singularly fixed, territorially bounded concepts of space. Though my purpose here is not to provide a taxonomy on city-regions, given that the city-region is the new and emerging subnational scalar focal point and territorial fix for the global capitalist economy, a critical reappraisal of the city-region concept is clearly one of the most urgent tasks facing economic geographers today. On this, city-region planning in England points towards a polity that lacks uniformity. Driven forward by the RDAs and the Core Cities Group it is noticeable that of the eight component city-regions of the Northern Way, only five - Liverpool, Manchester, Newcastle, Leeds and Sheffield - are based upon cities that form part of the Core Cities Group, with Central Lancashire, Tees Valley, and Hull \& the Humber ports a result of regional and national political fiat. Indeed the latest of these city-region strategies - Regional Cities East - is based upon six medium-sized provincial towns/cities, thus not containing any core city within its bounds. As such, the new city-regionalism does not constitute 
an internally consistent approach to the city-region in the academic literature, or the policy agenda of nation-states. Nor, for that matter, can the new cityregionalism be considered to refer to a single set of uniform processes operating both internally within, and externally across, city-regions. For sure, the challenge for economic geographers remains - to study emerging state spaces (such as city regions) and position them within an increasingly complex territorial, networked, and relational world. With this in mind, the second avenue for critical engagement is to explore the relationship between the city-region and the state.

\subsection{City-Regions and State Politics}

If, as we have discovered, the city-region is a slippery term that can be best described by what it is not, then understanding its function within national social formations becomes increasingly important. Perusing through the various literatures though, one could often be forgiven for thinking that the state had even less of a role in the new city-regionalism than it did previously in the new regionalism. Drawing comparisons with Storper's (1997) notion that we are living in a 'regional world', comprised of regional economies that are the building blocks for a networked and interconnected global state, according to more recent contributions, the increasing territorial interconnectivity between city-regions - to form what some have termed an archipelago economy (Veltz, 1996) - will often bypass the national-state (Taylor et al., 2002). Once too often though, this notion of bypassing the national-state has led to misinformed articulations rendering the state less important within the global matrix of subnational economic units that are increasingly viewed as 
the necessary scalar fix for maintaining competitiveness (Ohmae, 1995; 2001). It is argued that the political-economic impacts of globalisation, such that city-regions are coming to function as the basic motors of the global economy, has had marked effects on the authority of even the most powerful territorial states today (Scott et al., 2001). Thus, the new city-regionalism is seen by many to challenge the ideals and practices of citizenship, political representation, and democracy that have been bound up with the achievement of statehood as economic, cultural, social, and informational flows permeate and straddle the boundaries and territory of individual nationstates.

With the geographic structure of these relationally-networked cityregions tending "more and more to override purely political boundaries so that they are increasingly free from regulatory supervision on the part of national states" (Scott, 2001: 4) striking a chord with scalar debates that are demonstrating a stronger horizontal networking of territorial space - over and above the purely hierarchical ordering of scales from the global to the local - it is exactly this spatial transfiguration that reinforces the importance of the relationship between city-regions and the state. Though it can be argued that the new city-regionalism is "not so much an initiative flowing out from central government as it is a direct local response to stresses and strains set in motion by the emergence of the city-region as an important actor in the world economy" (Scott et al., 2001: 21), it is questionable whether this can justify claims that undermine the importance of the state, and the importance of understanding the state's role in shaping subnational territorial spaces. 
If the emergence of the new city-regionalism has challenged the authority of the state and made it even less important than it was previously seen to be throughout the period of new regionalist orthodoxy, then it would be easy to assume that the new city-regional agenda has, by default, partially overcome the accusation of being a poor framework through which to grasp the real connections between the regionalisation of business and governance and the changing role of the state. As in the new regionalism, where the state was the critical enabler of subnational economic restructuring - illustrated in the ascent, and subsequent demise, of the NRP in England (see Harrison, 2006a) - recognition of the evolving form of the state is critical for understanding city-regional development.

Of course, it should not be assumed that city-regions have replaced or flanked nation-states, nor that they have become detached from their respective nation-state ${ }^{\mathrm{ix}}$. More modestly, but no less importantly, the form and function of city-regions remain intimately tied into the evolution of new state formations. Once more, a perspective on this can be achieved through reference to the work of Dickinson, because the city-regionalism that he observed in the 1960 s served a very different function - redistribution - during the era of Keynesian macro-economic management, compared to the neoliberal development agenda of economic growth and competitiveness that city-regions service today. Indeed for me, the recognition that the reconfiguration of the state is becoming increasingly complex makes it even more critical than it was in the new regionalism to understand the complex restructuring of the state in governing new regional economic state spaces. Furthermore, it is believed that the politics surrounding the new city- 
regionalism in England can enlighten the need for critical reflection on the role of the state within reconstituted postnational capitalist space economies.

"Nothing less than the transformation of the North of England" was the vision that heralded the arrival of the Northern Way (NWSG, 2005: 6). Yet a strategy is not merely the sum of the activities that it proposes to undertake, because without resources, authority, and power these projects will remain in existence purely in pen and ink. Thus, the meagre $£ 100$ million growth fund earmarked for the Northern Way represents a rather paltry sum in comparison to the transformational agenda that it is to charged with delivering upon ${ }^{\mathrm{x}}$, and even more so when you break down this investment to realise that $£ 50 \mathrm{~m}$ of this growth fund has been contributed by the three northern RDAs. Any intention on behalf of the government to make further contributions, as had been speculated upon in the initial development of the Northern Way, have now been firmly blocked by the state. The future of the Northern Way now lies entirely with the three northern RDAs, given that for it to continue post-2008 when they will have committed the majority of their growth fund, the RDAs will have to fund the entire programme from within their own state-derived budget. More generally, the $£ 50 \mathrm{~m}$ state contribution to the Northern Way pales into insignificance when compared to the $£ 22$ bn commitment made by the same government a year earlier in the design for spatial growth in the Greater South East region (ODPM, 2003). Entirely consistent with the European Union's 'balanced competitiveness' agenda, this approach aims to bring up lagging cities/regions to a common standard without damaging the position of the leading cities/regions; and critically, it avoids the thorny political issue of addressing regional disparities that result from uneven development. 
Arguing that "the distinctive aspect of the role of resurgent cities in the new regionalism...is the departure from explanations that emphasise the importance of cities and regions within social redistributional national policy and political frameworks" (Ward and Jonas, 2004: 2121) these proponents of the new city-regionalism have a clear understanding of the need to remind readers that the national state continues to be the de facto animator of regional development. True, city-regions do seek to obtain partial territorial autonomy from the state and a degree of independent authority over local economic decision-making, but this should not be read as an attempt to replace or operate at a tangent to the national economy. In highlighting how the partial control that city-regions exhibit over the overall subnational governance framework in England, the evidence from England reinforces the assertion that the state retains near exclusivity in the control of regional development. The role of the state in this realm has thus shifted from that of the driving force in the design and implementation of strategies, to that of an enabler, facilitator, and catalyst in the multilevel metagovernance of the postnational regulatory framework; in this case, through the designated provision of legislative frameworks to assist institutional capacity building at the city-region level. Key to our understanding of the rescaling process has to be the recognition that it is never a neutral matter (Swyngedouw, 1997; Morgan, 2006). In contrast, "the rescaling of state functions and the assembling of institutions around city-regions is seen as a deliberate orchestration on the part of the state to the changing geographical logic of capitalism, where capitalism has been transformed from a nationally organised space economy to a globalised space of commodities, networks, 
and flows, within which state territorial hierarchies are collapsed through a process of stretching out" (Ward and Jonas, 2004: 2135). To this end, uncovering the role of the state in orchestrating the rescaling of powers is important, but it does not provide all the answers. For these answers we must look at broader patterns of state rescaling in, across, and between other scales of analysis.

\subsection{City-Regions or State Politics}

With remnants of the new regionalist orthodoxy retaining their presence in the English regions, city-regions add to an already complex and overcrowded political and regulatory set of frameworks. More than simply a need to focus on the orchestration and negotiation of responsibilities and competencies between city-regions and the state, complex territorial politics require unpacking subnationally between city-regions and regional state spaces (be they trans-regional, pan-regional, regional, or sub-regional). To this end, the new city-regionalism throws up new territorial issues, with the integration of the city-region with other economic units - across multiple levels of geographical territory and scale - the challenging agenda that necessitates a move towards more nuanced and textured understandings of the institutional role that city-regions occupy in economic policy. Once more, it is argued that the politics surrounding the new city-regionalism in England can enlighten this debate.

Over time there has been a long but somewhat sporadic engagement with policy instruments that represent the North of England, but where the Northern Way becomes particularly interesting in the context of this present 
discussion, is the territorially selective engagement with place. Given that the North of England does not actually represent an existing political entity, and that the programme is not actually a strategy for the entire territory, it appears reticent on behalf of the state to afford the programme the title of the Northern Way. Even more perplexing, the state's acknowledgement that there is a clear socioeconomic disparity between the north and the south in the rhetoric that underpins the programme - most clearly seen in the title - marks a clear shift in the government's thinking (compare with Blair, 1999). Despite initially being reported as an initiative coming from the RDAs and pressed upon Whitehall (Adams, 2004), as we have noted earlier, the Northern Way is another form of centrally orchestrated regionalism with the state in the vanguard of enacting metagovernance i.e. the governance of governance. Enabled by the state in the first instance, it was only subsequent to this that the RDAs and Core Cities Group were mobilised by the state to push the agenda forward, with the proviso that the state retained the (almost invisible) strong hand in controlling and determining the direction that the programme follows.

Developed in the same context as the failed NRP in England, the creation of the Northern Way is thus another illustration of 'state-sponsored' decentralisation where the central state legitimises the appropriate institutional fix that will occur subnationally (Tewdwr-Jones, 2006; cf. Scott, 2001). The problem here is that what may be viewed as appropriate by the state, may not be considered suitable at the local or regional levels. Indeed, one could argue that this evidences an inherent protectionist policy on the part of the state to protect its stance in the face of challenging processes of decentralisation and globalisation. 
Despite the government's decision to withdraw further funding for the Northern Way, if the three RDAs do decide to continue funding the programme, the state will retain its strong hand given that they have imposed strict output targets upon the RDAs for the state-derived funding that they administer. With no new funding going into the North of England, the Northern Way is a clear case of rescaling rather than resolving the problems of spatial disparities and uneven development. For the RDAs, this is proving a particularly difficult balancing act given that they are now promoting an unbounded networked conceptualisation of regional spatiality through their role in driving the Northern Way, and yet their day-to-day operations are explicitly bounded through the political-administrative nature of regions. Indeed, the relationship between the Northern Way city-region's and the RDA subregions in the economic geography of the north is unclear given that both operate at similar geographical scales and over similar territorial spaces. Indicative of the further entanglement of policy hierarchies, the events unfolding in England highlight how "competitive city-regionalism is best understood as an ongoing struggle for control of space rather than a new emergent form of capitalist territorial competition and development" (Ward and Jonas, 2004: 2135). In each case, the outcome has been the result of a centrally orchestrated regionalism that is once more illustrative of the importance of understanding the state's role in the governance of subnational economies. In recognising the centrality of the state, the inherent danger of this top-down approach is the tendency that identifying a new spatialanalytical structure will sacrifice careful examination of the causal structures and mechanisms that enable political-economic dividends to be accrued. A 
headlong rush into yet another policy initiative that promises salvation to lagging cities and regions is therefore flirting with the inherent danger of 'soft institutionalism' (MacLeod, 2001a).

\subsection{Soft Institutionalism and Policy Imitation}

Institutionalist political-economic restructuring has undoubtedly enriched the theoretical depth of new regionalist perspectives, and yet the academic and policy-induced tendency to read-off institutional developments from successful new regional state spaces retains an uneasy position at the core of their activity. Leading to the inherent dangers of 'soft institutionalism', the ascendancy to orthodoxy of the city-region as both an academic concept and as a policy magnet has led many of the leading competitive (and less competitive) cities and regions to be proactive in developing their own economic policies in pursuit of perceived competitive advantages from the institutionalisation of new systems of political-economic governance at the level of the city-region. Consensus that city-regions are coming to function as the basic motors of the global economy means that "city-regions today are facing enormous and unfamiliar pressures, so that they are being induced to search by trial and error for appropriate models of political response" (Scott, 2001: 4-5). If territories are induced into searching for city-regional policy models external to them, it can also be argued that territories are induced into searching internally, such that:

"There is a tendency to project the model of the global city-region elsewhere around the world, interpreting just about any manifestation 
of territorial specificity as a response to global restructuring. This constructed model is then propagated and sold back to urban and regional leaders as a model to emulate, so creating further material for the original observers. One is then forced to ask how far this model is an interpretation of the world and how far it is a mere construction."

Keating (2001: 375)

Once again, the emphasis placed upon 'construction' highlights the vitally important role that economic geographers have to play in understanding the city-region, as internal and external searches for an opportunity to engage in political-economic practice overtakes our critical and rational explanations of the new city-regionalism.

In practice, both internal and external searches for city-region policy models are clearly evident in recent political praxis in England. In the formulation and composition of the Northern Way there was a considerable amount of political manoeuvring following the initial selection of the five cityregions, based on the five core cities within the North of England - Liverpool, Manchester, Leeds, Sheffield and Newcastle. With little or no experience of city-region collaboration, the inclusion of the Hull \& Humber port, Tees Valley, and Central Lancashire in the Northern Way, and the subsequent development of city-region development plans in other territories - for example, through the development of a Midlands Way - provides evidence that the levels of policy imitation remain constant ${ }^{\mathrm{xi}}$ and that the construction of city-regions is 'done for a purpose'. Taken together, it is believed that this evidence adds weight to the argument that the weaknesses identified in the 
new regionalism have simply been collapsed into the new city-regionalism, with little or no consideration of their effects.

\section{$5 \quad$ Concluding comments}

Adding weight to recent arguments suggesting that "the city-region is in danger of becoming simply the latest in a long line of fashionable ideas" (Morgan, 2006: 1) this paper has sought to reinforce how in the most recent economic geography orthodoxies, the same weaknesses appear to undermine their theoretical position. As such, the new city-regionalism has been exposed as rescaling, rather than resolving, the weaknesses that signalled the fall from orthodoxy of the new regionalism. Talking up growth, through discourses of regional competitiveness (Bristow, 2005), and through the spatial and scalar reorganisation of the state from one scale to another in this case from the region to the city-region - merely distracts attention away from the state's inability to manage the capitalist tendency for uneven development. On this point, Ward and Jonas (2004) are quick to highlight in their critique how the new city regionalism is constructed narrowly around geographies of accumulation and competition, at the expense of knowledge of other kinds of economic geography; those of collective provision, consumption, labour regulation, uneven development, social regulation, and so forth.

As I have tried to illustrate in this paper, the new regional policy of the late 1990s, and now the emerging city-regional policy within government today are both constructs partly of a desire on behalf of the state to find an appropriate scale to perform the same economic growth function. As such, the 
displacement of the state into 'politically mediated institutional projects' (Jones, 2001) is indicative of the crisis tendencies exhibited by the state in maintaining its legitimacy for managing the economy; or what we have come to know in economic geography as the 'crisis of crisis management' (Offe, 1984). With the state continuing to direct and steer social and economic activity in the so-called national interest questions, the role of the nation-state, and in particular its relationship with subnational tiers of governance, will continue to dominate debates surrounding the rise of the city-region (TewdwrJones, 2006).

To understand the city-region, however, we must also recognise the role enacted by local and regional interests and local and regional states in explaining the rise of city-regionalism. For instance, England's Core Cities Group is an obvious example of a subnational spatial-political response to uneven development and a perceived disparity between the South East mega-city region and the remainder of England that has helped shape cityregionalism. However, as this paper has sought to illustrate, the capacity for self determination in subregional territories continues to be constrained and blunted by the state's ability to direct and steer these new governance mechanisms towards what is perceived to be in the national interest - at the obvious expense of local and regional interests whose capacity to shape the city-region agenda is constrained by this process. In the longer term, when the time does come to move beyond the new city-regionalism, a more critical stance needs to be adopted within economic geography; such that the inherent lines of weakness that undermined the new regionalism, and are now present in the new city-regionalism, are not merely rescaled or collapsed into 
a new orthodoxy in economic geography. The challenge that lies ahead is difficult, but it is one that we need to recognise as we move forward in economic geography. 


\section{BIBLIOGRAPHY}

Adams, J. (2004) 'In my view: the northern way'. The Journal 16 April.

Advantage West Midlands/East Midlands Development Agency (2005) Smart Growth: The Midlands Way Advantage West Midlands: Birmingham.

Allen, J., Massey, D. and Cochrane, A. (1998) Rethinking the Region. Routledge: London.

Amin, A. (2004) 'Regions unbound: towards a new politics of place.' Geografiska Annaler B, 86, 33-44.

Brenner, N. (1998) 'Between fixity and motion: accumulation, territorial organization and the historical geography of spatial scales.' Environment and Planning D-Society \& Space, 16, 459-481.

Brenner, N. (2004) New State Spaces - Urban Governance and the Rescaling of Statehood. Oxford University Press: Oxford.

Bristow, G. (2005) 'Everyone's a 'winner': problematising the discourse of regional competitiveness.' Journal of Economic Geography, 5, 285304.

Core Cities Group (2004) Our Cities Are Back - Competitive Cities make Prosperous Regions and Sustainable Communities. ODPM: London.

Department of Transport Local Government and the Regions/Cabinet Office (2002) Your Region, Your Choice: Revitalising the English Regions. DTLR/Cabinet Office: London.

Dickinson, R., (1964) The City Region in Western Europe. Routledge \& Kegan Paul: London. 
Dickinson, R. (1967) City and Region: A Geographical Interpretation. Routledge \& Kegan Paul: London.

Dickinson, R. (1976) Regional Concept: the Anglo-American leaders. Routledge and Kegan Paul: London.

Fawcett, C. B. (1919) Provinces of England: A Study of Some Geographical Aspects of Devolution. Williams and Norgate: London.

Hall, P. and Pain, K. (eds.) (2006) The Polycentric Metropolis - Learning from Mega-City Regions in Europe, Earthscan: London.

Hall, P., Thomas, R., Gracey, H. and Drewett, R. (1973) The Containment of Urban England. Allen and Unwin: London.

Harrison, J. (2006a) 'The Political Economy of Blair's "New Regional Policy".' Geoforum, 37, 932-943.

Harrison, J. (2006b) 'Re-Reading the New Regionalism: A Sympathetic Critique.' Space and Polity, 10, 21-46.

Hetherington, P. (2004) 'Communities and Sustainable Regeneration' at the Economic and Social Research Council's Regional Policy Conference. Durham.

HM Treasury, Office of the Deputy Prime Minister and Department of Trade and Industry (2004) Devolving Decision Making: 2 - Meeting the Regional Economic Challenge: Increasing Regional and Local Flexibility. HMSO: London.

HM Treasury, Office of the Deputy Prime Minister and Department of Trade and Industry (2006) Devolving Decision Making: 3 - Meeting the Regional Economic Challenge: The Importance of Cities to Regional Growth. HMSO: London. 
Jones, A., Williams, L., Coats, D., Lee, N. and O'Keefe, A. (2006a) Enabling Cities in the Knowledge Economy. The Work Foundation/DCLG: London.

Jones, M. (2001) 'The rise of the regional state in economic governance: 'partnerships for prosperity' or new scales of state power?' Environment and Planning A, 33, 1185-1211.

Jones, M., MacLeod, G. and Harrison, J. (2006b) 'In What Sense a Regional World? Institutional Legacies, Territorial Fixes, Network Topologies' at Whither Regional Studies in Association of American Geographers, Chicago.

Keating, M. (2001) 'Governing Cities and Regions: Territorial Restructuring in a Global Age'. In, (ed.) Scott, A., Global City-Regions: Trends, Theory, Policy. Oxford University Press: Oxford, 371-390.

Kelly, R. (2006) Keynote Speech. Core Cities Summit, Bristol. 26 June.

Lloyd, G. and Peel, D. (2006) 'City-Regionalism: The social reconstruction of an idea in practice'. In, (eds.) Tewdwr-Jones, M. and Allmendinger, P., Territory, Identity and Spatial Planning: Spatial Fragmentation in a Fragmented Nation. Routledge: London, 285-304.

Lovering, J. (1995) 'Creating Discourses Rather than Jobs: the Crisis in the Cities and the Transition Fantasies of Intellectuals and Policy Makers'. In, (eds.) Cameron, S., Davoudi, S., Graham, S. and Madami-Pour, A., Managing Cities: The New Urban Context. Wiley: England, 109-126.

Lovering, J. (1999) 'Theory led by policy: The inadequacies of the 'new regionalism' (illustrated from the case of Wales).' International Journal of Urban and Regional Research, 23, 379-395. 
Lovering, J. (2006) 'The New Imperial Geography'. In, (eds.) Bagchi-Sen, S. and Lawton Smith, H., Economic Geography: then, now and the future. Routledge: London, 221-232.

MacLeod, G. (2001a) 'Beyond soft institutionalism: accumulation, regulation, and their geographical fixes.' Environment and Planning A, 33, 11451167.

MacLeod, G. (2001b) 'New Regionalism Reconsidered: Globalisation and the Remaking of Political Economic Space.' International Journal of Urban and Regional Research, 25, 804-829.

Marshall, A. and Finch, D. (2006) City Leadership - Giving City-Regions the Power to Grow. IPPR Centre for Cities: London.

Marvin, S., Harding, A. and Robson, B. (2006) A Framework for City-Regions. ODPM: London.

Morgan, K. (2006) The Challenge of Polycentric Planning: Cardiff as a Capital City Region? Cardiff School of City and Regional Planning: Cardiff.

New Local Government Network (2005) Seeing the Light? Next Steps for City Regions. NLGN: London.

Northern Way Steering Group (2004) Moving Forward: The Northern Way First Growth Strategy Report. ONE: Newcastle.

Northern Way Steering Group (2005) Action Plan - Progress Report. Northern Way Growth Strategy Team: Newcastle-upon-Tyne.

Offe, C. (1984) Contradictions of the Welfare State. MIT Press: Cambridge, MA.

Office of the Deputy Prime Minister (2003) Sustainable Communities: building for the future. ODPM: London. 
Office of the Deputy Prime Minister (2004) Making it Happen - The Northern Way. ODPM: London.

Ohmae, K. (1995) The End of the Nation State: The Rise of Regional Economies. Harper Collins: London.

Ohmae, K. (2001) 'How to Invite Prosperity from the Global Economy into a Region'. In, (ed.) Scott, A., Global City-Regions: Trends, Theory, Policy. Oxford University Press: Oxford, 33-43.

Parr, J. B. (2005) 'Perspectives on the City-Region.' Regional Studies, 39, $555-566$.

Peck, J. and Tickell, A. (1995) 'The social regulation of uneven development: 'regulatory deficit', England's South East, and the collapse of Thatcherism.' Environment and Planning A, 27, 15-40.

Robson, B. (2005) 'Towards a Randstad of the North: attempts to tackle the growing regional economic disparities across Britain cannot succeed without a national spatial strategy (delivering sustainable communities).' Town and Country Planning, 18-19.

Scott, A. (1998) Regions and the World Economy: The Coming Shape of Global Production, Competition, and Political Order. Oxford University Press: Oxford.

Scott, A. (2001) Global City-Regions: Trends, Theory, Policy. Oxford University Press: Oxford.

Scott, A., Agnew, J., Soja, E. and Storper, M. (2001) 'Global city-regions'. In, (ed.) Scott, A., Global City-Regions: Trends, Theory, Policy. Oxford University Press: Oxford, 11-30. 
Storper, M. (1997) The Regional World: Territorial Development in a Global Economy. Guildford Press: New York.

SURF (2004) Releasing the National Economic Potential of English CityRegions: The Rationale for and Implications of a 'Northern Way'. SURF: Manchester.

Swyngedouw, E. (1997) 'Neither Global nor Local: "Glocalisation" and the Politics of Scale'. In, (ed.) Cox, K., Spaces of Globalisation. Guildford Press: New York, pp. 137-166.

Taylor, P. J., Catalano, G. and Walker, D. (2002) 'Measurement of the world city network.' Urban Studies, 39, 2367-2376.

Tewdwr-Jones, M., (2006) 'Identifying the determinants of the form of government, governance and spatial plan making'. In (ed.) TewdwrJones, M. and Allmendinger, P., Territory, Identity and Spatial Planning: Spatial governance in a fragmented nation. Routledge: London, pp. 353-365.

Tewdwr-Jones, M. and McNeill, D. (2000) 'The Politics of City-Region Planning and Governance.' European Urban and Regional Studies, 7, 119-134.

Thrift, N. (2004) 'Intensities of Feeling: Towards a Spatial Politics of Affect.' Geografiska Annaler B, 86, 57-78.

Tomaney, J., Hetherington, P. and Pinkney, E. (2004) Monitoring the English Regions. CURDS: University of Newcastle.

Town and Country Planning Association (2005) Smart Growth - The Midlands Way. TCPA Conference Flyer downloaded from: http://tcpa.org.uk/CONFERENCE_FILES/MidlandsWay0305.pdf 
Veltz, P. (1996) Mondialisation, villes et territoires: l'économie d'arichipel. Presses Universitaires de France: Paris.

Ward, K. and Jonas, A. (2004) 'Competitive city-regionalism as a politics of space: a critical reinterpretation of the new regionalism.' Environment and Planning $A, 36,2119-2139$.

'The pivotal role of Global City-Regions in the rise to orthodoxy of the new city-regionalism is particularly revealing given that it has its origins at the University of California, Los Angeles; the same institution that gave rise to the North American strand of the new regionalism in the mid-1990s (Storper, 1997; Scott, 1998).

ii This notion of the world as a space of flows held together by a network of cities has been centred on the work of the Globalisation and World Cities Research Group (GaWC) based at Loughborough University (http://www.lboro.ac.uk/gawc).

iii The author deliberately chooses to omit Northern Ireland, where despite the devolved power sharing Executive currently lying dormant, it would be argued that the institutional settlement remains settled - unlike in England.

iv This is not, however, a terminal blow to the NRP given that although the regional project was dealt a heavy blow in the North East referendum, it is clear that in certain quarters especially HM Treasury - regions continue to occupy the attention of political and economic strategists involved in promoting economic growth and the restructuring of the state architecture in England. While one group of reformers, led by the government ministers Ruth Kelly and David Milliband and the centre-left IPPR think-tank, are pushing the city-region agenda hard, another group that brings together the economist Ed Balls and John Healey (from HM Treasury) alongside the New Local Government Network think-tank, are seeking to re-empower the existing regions.

${ }^{v}$ Ken Livingstone was the former leader of the Greater London Council that was famously dissolved by Margaret Thatcher in 1986.

vi These were the Thames Gateway, Milton Keynes \& South Midlands, Ashford, and LondonStansted-Cambridge-Peterborough. 
vii At the time, John Adams was Research Director at the Institute for Public Policy Research (IPPR) North, a centre-left political think-tank.

viii Strategy development in the South West and East of England is very interesting given that both initiatives focus specifically on their own region, and do not traverse regional boundaries. While this does not make their strategies trans-regional, they do highlight the importance of trans-regional flows to regional development.

${ }^{\text {ix }}$ As Ward and Jonas (2004: 2126) rightly argue, each of these positions "precludes counterarguments to the effect that national states must fundamentally be self-interested in ensuring that city-regions in their territories continue to generate growth, jobs, wealth, and tax revenue".

${ }^{x}$ This equates to a mere $0.001 \%$ of total public expenditure in the North of England.

${ }^{x i}$ In the case of Central Lancashire, the fact that it was not a city-region did not prevent them from latching onto the notion of how polycentric city-regions have been successful in other regions to successfully convince policymakers that they warranted a place within the Northern Way. 